ISSN 1392-3196 / e-ISSN 2335-8947

Zemdirbyste-Agriculture, vol. 108, No. 4 (2021), p. 347-354

DOI 10.13080/z-a.2021.108.044

\title{
Autochthonous plant growth-promoting rhizobacteria enhance Thymus vulgaris growth in well-watered and drought-stressed conditions
}

\author{
Dragana STAMENOV ${ }^{1}$, Simonida DJURIC ${ }^{1}$, Timea HAJNAL-JAFARI ${ }^{1}$, \\ Snežana ANDJELKOVIĆ \\ ${ }^{1}$ University of Novi Sad, Faculty of Agriculture \\ 21000 Novi Sad, Serbia \\ E-mail: simonida@polj.uns.ac.rs \\ ${ }^{2}$ Institute for Forage Crops \\ 37251 Kruševac, Serbia
}

\begin{abstract}
The use of plant growth-promoting rhizobacteria (PGPR) in the production of medicinal plants is crucial, because agricultural chemicals are no longer acceptable in their production. This paper discusses the results of a recent study undertaken to isolate and characterize PGPR isolates of Bacillus, Pseudomonas and Azotobacter from common thyme (Thymus vulgaris L.) rhizospheric soil and monitor the effect of their application on seed germination and plant growth. The effect of selected isolates on seed germination and initial growth of common thyme was examined in controlled conditions. The impact of the isolates on the content of biochemical stress markers (total phenols and lipid peroxidation intensity) in germinated seeds was determined. The influence of the isolates on the plant growth under well-watered conditions (watered to $80 \%$ of water holding capacity (WHC)) and under water deficit stress (watered to $40 \%$ of WHC) was evaluated by measuring plant root and stem length in semi-controlled conditions.

This study confirmed that indigenous rhizospheric bacteria of common thyme have multiple plant growthpromoting (PGP) properties. Among Bacillus 10 isolates, Pseudomonas 12 isolates and Azotobacter 9 isolates, only Pseudomonas isolate (P53) had all the tested PGP properties. The applied isolates had a positive effect on the examined plant growth parameters. The highest percentage of germination was determined in the treatment with P53 isolate (96\%). The highest response for vigour index was observed with isolate A1 (3807\%). All isolates, except B58 and B60, reduced stress by lowering the amount of both or at least one stress related molecules. The results of the experiment led to the conclusion that isolates Azotobacter sp. A1 and Pseudomonas sp. P53, both ACC-deaminase-producing bacteria, have the best effect on plant growth under well-watered and drought-stressed conditions, which indicates their potential to be used as a biofertiliser for promoting common thyme growth.
\end{abstract}

Key words: common thyme, medicinal plants, drought, biofertiliser, ACC-deaminase.

\section{Introduction}

Today, agriculture is facing a double challenge: (1) to reduce application of agrotechnical measures that negatively affect soil structure and function and (2) to adapt to the expected consequences of climate change, including foremost heavy rains and droughts, but also new pests, plant diseases and weeds. All these climatechange consequences lead to decreased plant yield and crop quality (Pilli et al., 2019). Precisely for all these reasons, in the world, more and more attention is being given to agriculture based on the principles of sustainable production, which implies significant changes in crop cultivation technology. Introduction of live plant growthpromoting rhizobacteria (PGPR) into the soil completely fits the sustainable production system (Vejan et al., 2016). PGPR are a heterogeneous group of microorganisms that can cause plant growth promotion and/or biological control

of plant diseases and can be found in the rhizosphere, at root surface and in association with roots (Gusain, Bhandari, 2019). The use of microbiological formulations containing effective PGPR may reduce the use of chemical fertilisers such as nitrogen and phosphorus fertilisers and of chemical pesticides.

Nowadays, microbiological formulations have an essential role as supplements to enhance the growth and yield of several agricultural, horticultural and medicinal plants (Kenneth et al., 2019). As a result of the PGPR application, these plants' resistance to drought, excessive moisture and diseases is increased, and the dynamics of microbiological processes in the soil are intensified resulting in improved soil fertility (Aini et al., 2019).

The use of PGPR in the production of medicinal plants is crucial, because agricultural chemicals,

Please use the following format when citing the article:

Stamenov D., Djuric S., Hajnal-Jafari T., Andjelković S. 2021. Autochthonous plant growth-promoting rhizobacteria enhance Thymus vulgaris growth in well-watered and drought-stressed conditions. Zemdirbyste-Agriculture, 108 (4): $347-354$. DOI 10.13080/z-a.2021.108.044 
including various pesticides (herbicides, insecticides and fungicides) and fertilisers, are no longer acceptable (Malik et al, 2011). Some research studies around the world show that PGPR can be used very successfully in the production of medicinal plants. It was found that microorganisms increase the medicinal plants' resistance to drought, high and low temperatures and different soil salt levels (Jahanian et al., 2012). In addition, the positive influence of microorganisms' application on the production of biologically active substances of medicinal plants was also confirmed (Köberl et al., 2013).

The rhizosphere of medicinal plants is very specific and supports a great diversity of microorganisms including PGPR (Ahmed et al., 2014). However, although the rhizosphere of medicinal plants is very specific, it is still insufficiently examined (Zhang et al., 2020).

The aromatic and medicinal properties of the genus Thymus have made it one of the most important medicinal plants. Thymus vulgaris (L.), generally called common or garden thyme, is one of the most popular species of this genus. It is frequently used as herbal tea, flavouring agent (condiment and spice) and aromatic and medicinal plant. As reported by Nguyen and Niemeyer (2008), agronomical factors and applied cultivation methods can modify the composition and change quantity of active substances of common thyme plant. Research results of Abdollahi Arpanahi et al. (2019) show that the PGPR can be successfully used in production of Thymus daenensis. However, most of the applied isolates were not isolated from the rhizosphere of Thymus sp. Limited studies have been undertaken on autochthonous species of rhizospheric soil of common thyme and their plant growth-promoting potential (Ahmed et al., 2014).

The aim of this study was to isolate and characterize PGPR isolates of Bacillus, Pseudomonas and Azotobacter from Thymus vulgaris rhizospheric soil and monitor the effect of their application on seed germination and plant growth under water deficit stress and well-watered conditions.

\section{Materials and methods}

The experiment was carried out in 2020 at Faculty of Agriculture, University of Novi Sad, Serbia.

Isolation of Bacillus, Pseudomonas and Azotobacter isolates. Microorganisms of the genus Bacillus, Pseudomonas and Azotobacter were isolated from the rhizospheric soil samples of common thyme (Thymus vulgaris L.) at the locality Rimski Šančevi

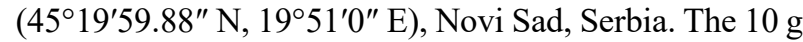
of rhizospheric soil was suspended in $90 \mathrm{ml}$ of sterile saline solution and shaken for $10 \mathrm{~min}$ at $180 \mathrm{rpm}$ on a rotary shaker. After that, the soil suspension was diluted in four-fold steps in glass tubes to an end point dilution of $10^{-5}$. One hundred microliters of the dilutions $\left(10^{-1}\right.$ to $\left.10^{-5}\right)$ were spread for Bacillus strains on an appropriate selective medium L-agar: sodium chloride $0.5 \mathrm{~g} \mathrm{~L}^{-1}$, tryptone $10 \mathrm{~g} \mathrm{~L}^{-1}$, yeast extract $5 \mathrm{~g} \mathrm{~L}^{-1}$, agar $15 \mathrm{~g} \mathrm{~L}^{-1}$, for Pseudomonas strains on King's B medium: proteose peptone $20 \mathrm{~g} \mathrm{~L}^{-1}$, $\mathrm{K}_{2} \mathrm{HPO}_{4} 1.5 \mathrm{~g} \mathrm{~L}^{-1}, \mathrm{MgSO}_{4} \times 7 \mathrm{H}_{2} \mathrm{O} 1.5 \mathrm{~g} \mathrm{~L}^{-1}$, glycerol $10 \mathrm{ml}$ $\mathrm{L}^{-1}$, agar $15 \mathrm{~g} \mathrm{~L}^{-1}$, and for Azotobacter strains on F-agar: $\mathrm{K}_{2} \mathrm{HPO}_{4} 0.3 \mathrm{~g} \mathrm{~L}^{-1}, \mathrm{CaHPO}_{4} 0.2 \mathrm{~g} \mathrm{~L}^{-1}, \mathrm{MgSO}_{4} 0.3 \mathrm{~g} \mathrm{~L}^{-1}$, $\mathrm{NaCl} 0.5 \mathrm{~g} \mathrm{~L}^{-1}, \mathrm{FeCl}_{3} 0.1 \mathrm{~g} \mathrm{~L}^{-1}, \mathrm{CaCO}_{3} 2.5 \mathrm{~g} \mathrm{~L}^{-1}$, solution of microelements $1 \mathrm{ml} \mathrm{L}^{-1}$, agar $16 \mathrm{~g} \mathrm{~L}^{-1}$, and incubated at $28^{\circ} \mathrm{C}$ temperature for 2 days.

Isolates consisting of catalase-positive, grampositive and rod-forming cells forming endospores were selected as Bacillus isolates. The presence of catalase was detected by taking a drop of $3 \% \mathrm{H}_{2} \mathrm{O}_{2}$ (hydrogen peroxide), which was added to $48 \mathrm{~h}$ old bacterial colony. The appearance of oxygen bubbles indicated catalase activity. Isolates that were found to be gram-negative, rod-shaped and to produce the pigment fluorescein were picked out as Pseudomonas isolates. Fluorescein production was tested on Pseudomonas Flo agar: proteose pepton $20 \mathrm{~g} \mathrm{~L}^{-1}$, bacto maltose $10 \mathrm{~g} \mathrm{~L}^{-1}, \mathrm{~K}_{2} \mathrm{HPO}_{4} 1.5 \mathrm{~g} \mathrm{~L}^{-1}, \mathrm{MgSO}_{4} 0.73 \mathrm{~g} \mathrm{~L}^{-1}$, glycerol $10 \mathrm{ml} \mathrm{L}^{-1}$, agar $15 \mathrm{~g} \mathrm{~L}^{-1}$ (Soesanto et al., 2011). As Azotobacter isolates, milky-white, mucous colonies that were found to be Gram-negative, cocoid with a mucous capsule were selected.

Plant growth-promoting (PGP) activities. A qualitative assay of indole-3-acetic acid (IAA) production was conducted in tryptophan broth, containing $5 \mathrm{mmol}$ $\mathrm{L}^{-1}$ tryptophan (Etesami et al., 2015). The ability of the isolates to produce the enzyme tryptophanase, specifically the presence of indole in the medium, was proven by the addition of Kovac's reagent and the formation of a red ring. The ability to produce siderophores was determined using chrome-azurol S (CAS) agar (Schwyn, Neilands, 1987). The change of the medium colour from blue green to orange reddish was proof that the microorganism produces siderophores. Hydrogen cyanide (HCN) production was tested on the medium with glycine: soy tripton $30 \mathrm{~g} \mathrm{~L}^{-1}$, glycine $4.4 \mathrm{~g} \mathrm{~L}^{-1}$, agar $15 \mathrm{~g} \mathrm{~L}^{-1}$, following the protocol as reported by Frey-Klett et al. (2005). The ability to mineralize organic phosphorus compounds was investigated on a Menkina substrate (Liu et al., 2011) with minor changes: glucose $10 \mathrm{~g} \mathrm{~L}^{-1},\left(\mathrm{NH}_{4}\right)_{2} \mathrm{SO}_{4} 0.5 \mathrm{~g} \mathrm{~L}^{-1}, \mathrm{NaCl}$ $0.3 \mathrm{~g} \mathrm{~L}^{-1}, \mathrm{KCl} 0.3 \mathrm{~g} \mathrm{~L}^{-1}, \mathrm{MgSO}_{4} \times 7 \mathrm{H}_{2} \mathrm{O} 0.3 \mathrm{~g} \mathrm{~L}^{-1}, \mathrm{FeSO}_{4}$ $\times 7 \mathrm{H}_{2} \mathrm{O} 0.03 \mathrm{~g} \mathrm{~L}^{-1}, \mathrm{MnSO}_{4} \times \mathrm{H}_{2} \mathrm{O} 0.03 \mathrm{~g} \mathrm{~L}^{-1}, \mathrm{Ca}_{3}\left(\mathrm{PO}_{4}\right)_{2}$ $0.7 \mathrm{~g} \mathrm{~L}^{-1}$, lecithin $2 \mathrm{~g} \mathrm{~L}^{-1}$, agar $16 \mathrm{~g} \mathrm{~L}^{-1}$. The ability of isolates to solubilize inorganic phosphates was tested on Pikovskaya's agar plates: glucose $10 \mathrm{~g} \mathrm{~L}^{-1}, \mathrm{Ca}_{3}\left(\mathrm{PO}_{4}\right)_{2}$ $5 \mathrm{~g} \mathrm{~L}^{-1},\left(\mathrm{NH}_{4}\right)_{2} \mathrm{SO}_{4} 0.5 \mathrm{~g} \mathrm{~L}^{-1}, \mathrm{NaCl} 0.2 \mathrm{~g} \mathrm{~L}^{-1}, \mathrm{MgSO}_{4} \times$ $7 \mathrm{H}_{2} \mathrm{O} 0.1 \mathrm{~g} \mathrm{~L}^{-1}, \mathrm{KCl} 0.2 \mathrm{~g} \mathrm{~L}^{-1}$, yeast extract $0.5 \mathrm{~g} \mathrm{~L}^{-1}$, $\mathrm{MnSO}_{4} \times \mathrm{H}_{2} \mathrm{O} 0.002 \mathrm{~g} \mathrm{~L}^{-1}, \mathrm{FeSO}_{4} \times 7 \mathrm{H}_{2} \mathrm{O} 0.002 \mathrm{~g} \mathrm{~L}^{-1}$, agar $16 \mathrm{~g} \mathrm{~L}^{-1}$ (Wahyudi et al., 2011). After $5^{2}$ days of incubation at $28^{\circ} \mathrm{C}$ temperature, the appearance of transparent zones around the colonies was evidence of the ability of the microorganism to dissolve phosphates.

The capacity to produce 1-aminocyclopropane1-carboxylate (ACC)-deaminase was determined as reported by Pastor et al. (2016) with minor changes. First, isolates were grown overnight in nutrient agar for Bacillus and Pseudomonas isolates and in F-agar for Azotobacter isolates. After that the isolates were transferred to a liquid medium composed of $1 \mathrm{~g} \mathrm{~K}_{2} \mathrm{PO}_{4} \mathrm{H}, 0.2 \mathrm{~g} \mathrm{MgSO}_{4}$ $\times 7 \mathrm{H}_{2} \mathrm{O}, 0.1 \mathrm{~g} \mathrm{SO}_{4} \mathrm{Fe} \times 7 \mathrm{H}_{2} \mathrm{O}, 1 \mathrm{~g} \mathrm{CaCO}_{3}, 0.2 \mathrm{~g} \mathrm{NaCl}$, $5 \mathrm{mg} \mathrm{NaMoO}+2_{4} \mathrm{H}_{2} \mathrm{O}, 10 \mathrm{~g}$ glucose and $0.3 \mathrm{~g}$ of ACC as $\mathrm{N}$ source, per litre. Control treatment contained the same medium without ACC. After inoculation of both media, the culture was incubated at $28^{\circ} \mathrm{C}$ temperature on a rotary shaker at $130 \mathrm{rpm}$ for $48 \mathrm{~h}$. Isolate growth in medium with ACC, which was determined when the culture medium became cloudy, and absence of growth in control medium confirmed the ability of ACC utilization as $\mathrm{N}$ source. 
Evaluation of isolates for their PGP potential on thyme plants. Common thyme seeds used in the experiment were taken from the collection of Institute of Field and Vegetable Crops, Novi Sad, Serbia. The effect of selected isolates on seed germination and initial growth of common thyme was examined in controlled conditions. Before inoculation, the seed sterilization was performed by $70 \% \mathrm{C}_{2} \mathrm{H}_{6} \mathrm{O}$ (ethanol) and $0.1 \% \mathrm{HgCl}_{2}$ (mercury chloride) solution and rinsing with sterile water. For germination, 50 seeds inoculated with the appropriate bacteria were placed on filter paper at $22^{\circ} \mathrm{C}$ temperature. After 3 and 7 days, the number of germinated seeds was determined. The shoot and root length of germinated seeds was measured after 7 and 10 days. Vigour index and biochemical stress markers (total phenols and lipid peroxidation intensity) were measured after 10 days. The vigour index $(\mathrm{VI})$ was calculated as: VI $(\%)=($ mean root length + mean shoot length) $\times$ germination $\%$. The content of malondialdehyde (MDA), one of the products of membrane lipid degradation in cells, was used as a measure of lipid peroxidation intensity. The intensity of lipid peroxidation was determined based on the MDA content extracted from fresh plant material using a mixture of 2-thiobarbituric acid (TBA) and trichloroacetic acid (TCA) (Jambunathan, 2010). Total phenols in methanol extracts of seedlings were determined based on the reaction of phenols with Folin-Ciocalteu reagent (Makkar et al., 2007).
The influence of the isolates on the plant growth under well-watered conditions: watered to $80 \%$ of water holding capacity (WHC), and under water deficit stress: watered to $40 \%$ of WHC, was evaluated in semicontrolled conditions: in pots with a volume of $800 \mathrm{ml}$, at room $\left(25 \pm 2{ }^{\circ} \mathrm{C}\right)$ temperature and natural daylight photoperiod. The pots were filled with Klasmann substrate (Germany) up to $2 \mathrm{~cm}$ below the top. Before sowing, $10 \mathrm{ml}$ of inoculate of each selected isolate (titre $10^{9} \mathrm{CFU} \mathrm{ml}^{-1}$ ) was introduced into the substrate. A control pot was without inoculation. In each pot, $7 \mathrm{mg}\left(7 \mathrm{~kg} \mathrm{ha}^{-1}\right)$ of thymus seeds was sown. Each treatment had 8 pots: 4 pots were regularly watered, and the other 4 pots were exposed to drought (water deficit stress). After 30 days, the stem and root length of the plant was measured.

Statistical analysis. The data were statistically processed using the software Statistica, version 13,3 (TIBCO Software Inc.). The significance of the difference between the applied treatments was determined using Fisher's protected least significant difference (LSD) test.

\section{Results and discussion}

From the rhizospheric soil of common thyme, 9 bacterial isolates belonging to Azotobacter (denoted by letter A), 12 to Pseudomonas (denoted by letter P) and 10 to Bacillus (denoted by letter B) genus were isolated. Plant growth-promoting properties of the isolates are presented in Table 1.

Table 1. Plant growth-promoting properties of the isolates isolated from common thyme rhizosphere

\begin{tabular}{|c|c|c|c|c|c|c|}
\hline Isolate & IAA & Siderophore & $\begin{array}{l}\text { Hydrogen } \\
\text { cyanide } \\
\text { (HCN) }\end{array}$ & $\begin{array}{l}\text { Phosphate } \\
\text { mineralization }\end{array}$ & $\begin{array}{l}\text { Phosphate } \\
\text { solubilization }\end{array}$ & $\mathrm{ACC}$ \\
\hline A1 & + & - & +++ & + & ++ & + \\
\hline A2 & + & - & +++ & + & ++ & + \\
\hline A3 & - & - & + & + & + & - \\
\hline A4 & - & - & + & + & + & - \\
\hline A5 & + & - & - & + & + & - \\
\hline A6 & - & - & + & + & + & - \\
\hline A7 & - & - & + & + & + & - \\
\hline A8 & - & - & + & + & + & - \\
\hline A9 & + & - & - & + & + & - \\
\hline P21 & + & ++ & +++ & ++ & + & - \\
\hline $\mathrm{P} 22$ & + & + & ++ & ++ & ++ & - \\
\hline P23 & + & ++ & +++ & ++ & - & - \\
\hline $\mathrm{P} 24$ & + & + & + & + & + & - \\
\hline P25 & + & + & + & + & - & - \\
\hline P26 & + & + & ++ & + & - & - \\
\hline $\mathrm{P} 27$ & + & + & - & + & + & - \\
\hline P28 & + & + & - & + & + & - \\
\hline P50 & + & + & ++ & + & - & - \\
\hline P51 & + & + & - & + & - & - \\
\hline P52 & - & + & ++ & + & - & - \\
\hline P53 & + & ++ & ++++ & ++ & + & + \\
\hline B58 & - & ++ & + & ++ & - & - \\
\hline B59 & + & ++ & + & ++ & + & - \\
\hline $\mathrm{B} 60$ & - & ++ & +++ & ++ & ++ & - \\
\hline B61 & - & + & + & + & - & - \\
\hline B62 & - & + & - & + & - & - \\
\hline B63 & - & + & + & + & - & - \\
\hline B64 & - & + & + & + & - & - \\
\hline B65 & - & - & - & + & + & - \\
\hline B66 & - & - & - & + & + & - \\
\hline B67 & - & + & + & - & + & - \\
\hline $\begin{array}{l}\% \text { of positive reaction } \\
\text { from total }\end{array}$ & 54.8 & 64.5 & 74.2 & 96.8 & 64.5 & 9.7 \\
\hline
\end{tabular}

Note. + - IAA (indole-acetic acid) production, - - not detected; width of orange zone: -- no zone, $+-1-5 \mathrm{~mm},++-5-20 \mathrm{~mm}$, $+++-20 \mathrm{~mm}$; HCN production evaluated according to colour and its intensity: +- minimal, ++- medium, +++- large, ++++ - the largest; - - not detected; effectiveness of phosphate solubilization and mineralization of phosphorus organic compounds evaluated according to zone diameter: $+-4 \mathrm{~mm}_{\text {day }}^{-1},++-\geq 5 \mathrm{~mm}^{-1 a y^{-1}}$; ACC (1-aminocyclopropane-1-carboxylate)-deaminase activity: + - presence, -- absence. 
Among the nine Azotobacter isolates, 4 isolates were able to produce IAA, 7 isolates $-\mathrm{HCN}$ and 2 isolates exhibited ACC-deaminase activity. All isolates had the ability to mineralize and solubilize phosphorus, and none of the isolates were positive for siderophores production. All Pseudomonas isolates with one exception (P52) produced IAA, and all were positive for the siderophore production showing an orange zone on the CAS agar. For hydrogen cyanide ( $\mathrm{HCN})$ production, 9 isolates were found positive and only 1 for ACC-deaminase activity. All the isolates tested positive for phosphorus mineralization and 6 for phosphorus solubilization. Among 10 Bacillus isolates, only one (B59) isolate was positive for IAA production forming red ring during the indole test. Siderophores and $\mathrm{HCN}$ produced 8 isolates, while none showed ACC-deaminase activity. All the isolates were able to mineralize and 6 to solubilize phosphorus.

The obtained results showed that only one isolate (P53) had all plant growth-promoting (PGP) properties, while the other isolates did not. They differed in regard to their PGP abilities. The number of P-solubilizing microorganisms, P-mineralizers as well as HCNproducing isolates was higher than that able to produce IAA, siderophors and ACC-deaminase. Only 3 isolates were able to use ACC as a source of nitrogen. Malleswari and Bagyanarayan (2013) reported similar results in their evaluation of PGP activities of bacterial isolates from the rhizosphere of 10 medicinal and aromatic plants: Coleus forskohlii, Andrographis paniculata, Withania somnifera, Ocimum sanctum, Aloe vera, Tagetes erecta, Mimosa pudica, Artemisia vulgaris, Acorus calamus and Mentha spicata. During the experiment, 201 bacterial isolates showed ammonia production, 186 - IAA production, 43 - P-solubilizing activity and $58-\mathrm{HCN}$ production. Moreover, Ahmed et al. (2014) demonstrated that selected isolates from the rhizospheric soil of 11 different medicinal plants did not possess all PGP traits. According to the results of this experiment, among the 112 isolates, or $32.14 \%$, showed IAA production, $34.82 \%$ - P-solubilizing activity, 22.32\% - HCN production and 93.75\% - K-solubilization. Similar findings have been reported by Shakeela et al. (2017).

Depending on PGP properties, to examine their effect on seed germination, root and shoot length of seedlings and vigour index, 9 representative isolates: A1, A2, P21, P22, P23, P53, and B58, B59 and B60, were chosen (Table 2).

Table 2. Seed germination, root and shoot length and vigour index of common thyme

\begin{tabular}{|c|c|c|c|c|c|c|c|c|}
\hline \multirow{3}{*}{ Isolate } & \multirow{3}{*}{ 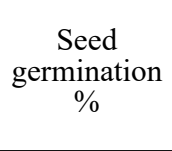 } & \multirow{2}{*}{\multicolumn{2}{|c|}{$\begin{array}{l}\text { No. of germinated seeds, } \\
\text { out of } 50 \text { seeds }\end{array}$}} & \multicolumn{2}{|c|}{ Root length mm } & \multicolumn{2}{|c|}{ Shoot length mm } & \multirow{3}{*}{$\begin{array}{c}\text { Vigour } \\
\text { index } \\
\%\end{array}$} \\
\hline & & & & \multirow{2}{*}{7 days } & \multirow{2}{*}{10 days } & \multirow{2}{*}{7 days } & \multirow{2}{*}{10 days } & \\
\hline & & 3 days & 7 days & & & & & \\
\hline A1 & 90 & $45 d$ & $50 \mathrm{a}$ & $11.7 \mathrm{ac}$ & $12.3 \mathrm{ab}$ & $23.3 \mathrm{~d}$ & $30.0 \mathrm{a}$ & 3807.0 \\
\hline A2 & 90 & $45 \mathrm{~d}$ & $49 \mathrm{a}$ & $11.7 \mathrm{ac}$ & $13.0 \mathrm{a}$ & $23.3 \mathrm{~d}$ & $25.0 \mathrm{bcd}$ & 3420.0 \\
\hline P21 & 88 & $44 d$ & $50 \mathrm{a}$ & $9.3 \mathrm{abc}$ & $10.0 \mathrm{abcd}$ & $21.7 \mathrm{dc}$ & $28.0 \mathrm{ab}$ & 3344.0 \\
\hline $\mathrm{P} 22$ & 90 & $45 \mathrm{~d}$ & $50 \mathrm{a}$ & $6.3 \mathrm{bc}$ & $7.0 \mathrm{de}$ & $19.3 \mathrm{dc}$ & 24.0 bcdef & 2790.0 \\
\hline $\mathrm{P} 23$ & 88 & $44 \mathrm{~d}$ & $50 \mathrm{a}$ & $13.3 \mathrm{a}$ & $11.0 \mathrm{abc}$ & $22.0 \mathrm{dc}$ & $26.0 \mathrm{abc}$ & 3256.0 \\
\hline P53 & 96 & $48 \mathrm{a}$ & $50 \mathrm{a}$ & $7.0 \mathrm{bc}$ & $6.7 \mathrm{de}$ & $11.3 \mathrm{ab}$ & $21.0 \mathrm{def}$ & 2659.2 \\
\hline B58 & 80 & $40 \mathrm{c}$ & $50 \mathrm{a}$ & $6.3 \mathrm{bc}$ & $7.0 \mathrm{de}$ & $16.3 \mathrm{ac}$ & $20.3 \mathrm{ef}$ & 2184.0 \\
\hline B59 & 80 & $40 \mathrm{c}$ & $49 \mathrm{a}$ & $9.3 \mathrm{abc}$ & 9.0 bcde & $22.0 \mathrm{dc}$ & 24.7 bcde & 2696.0 \\
\hline B60 & 88 & $44 d$ & $49 \mathrm{a}$ & $9.0 \mathrm{abc}$ & 8.3 cde & $22.3 \mathrm{dc}$ & $23.3 \mathrm{cdef}$ & 2780.8 \\
\hline Control & 68 & $34 \mathrm{~b}$ & $49 \mathrm{a}$ & $5.3 \mathrm{~b}$ & $6.3 \mathrm{e}$ & $10.3 \mathrm{~b}$ & $20.0 \mathrm{f}$ & 1788.4 \\
\hline
\end{tabular}

Note. Values in the same column followed by different letters indicate significant differences $(p<0.05)$ between the means.

During the experiment, the applied isolates had positive influence on seed germination. After 3 days, all isolates significantly enhanced the number of germinated seeds. The highest germination percentage $(96 \%)$ was determined in the treatment with P53 isolate, while in the control treatment the percentage was the lowest $(68 \%)$. After 7 days, in all treatments almost all seeds were germinated. These results suggest that the isolates were able to speed up the beginning of seed germination.

During the experiment, the application of the isolates resulted in increased root and shoot length of germinated seeds. On average, the best results were achieved with isolates A1, A2, P21 and P23. All isolates increased seedling vigour. The highest response for vigour index was observed with isolates A1, A2, P21 and P23.

It is well-known that PGP microorganisms can increase the rate of seed germination and vigour index (Shaukat et al., 2006). Although PGPR have been broadly used to improve seed germination and enhance the yield of many plants in different agroecosystems, there is a shortage of literature on seed germination and vigour index in medicinal and aromatic species (Ghorbanpour et al., 2015). Jahanian et al. (2012) investigated the influence of Azotobacter, Azospirillum and Pseudomonas isolates on seed germination and early growth characteristics of artichoke (Cynara scolymus L.). The results showed that the combination of these three isolates produced the best results regarding the investigated parameters. Rathaur et al. (2012) reported that Pseudomonas sp. isolate P-35 with many PGP traits significantly increased seed germination of Indian ginseng (Withania somnifera (L.) Dunal) plants. The positive effect of inoculation on germination and vigour index of medicinal plants has also been reported by Lenin and Jayanthi (2012).

However, some studies show that certain PGP strains can negatively affect germination rate and initial growth. According to Ghorbanpour and Hatami (2013), the two isolates Psedomonas putida (PP-168) and P. fluorescens (PF-187) had remarkable positive effect on plant vigour index and germination rate, while other 
Pseudomonas strains had a negative effect indicating that Pseudomonas isolates can have contrasting effect on vigour index. According to Siddiqui et al. (2006), the reason why some isolates have an inhibitory effect on germination rate and vigour is the ability of isolates to produce $\mathrm{HCN}$, which is a gas that in large quantities inhibits germination and growth of plant roots. In the study Stamenov et al. (2014), HCN producing Bacillus and Pseudomonas isolates had negative effect on seed germination of perennial ryegrass. Similarly, Heydari et al. (2008) determined the inhibitory effect of the HCN producing Pseudomonas on germination of wheat and rye. In contrast to the latter two studies, in the present study, all isolates positively affected germination rate and vigour index, although they had the ability to produce $\mathrm{HCN}$.
The PGP microorganisms play an important role in promoting tolerance of plants to abiotic stresses (Yasmin et al., 2019). The total phenols and lipid peroxidation intensity indicate the plant response to stress. Higher values of these two parameters mean greater possibility that the cell is in oxidative stress. When the values obtained in the treatment with the applied isolates were compared with those obtained in the control treatment, it was found that all isolates (except for B58 and B60) reduced stress by lowering the amount of both or at least one stress related molecules, while both of these two isolates increased it (Table 3).

Results of our experiment are in line with Kumar et al. (2016), who examined the influence of PGPR on the levels of total phenols and lipid peroxidation intensity

Table 3. Content of biochemical stress markers in germinated seeds of common thyme

\begin{tabular}{ccc}
\hline Isolate & $\begin{array}{c}\text { Total phenols } \\
\mathrm{mg} \mathrm{g}^{-1}\end{array}$ & $\begin{array}{c}\text { Lipid peroxidation intensity } \\
\mathrm{nmol} \mathrm{g}^{-1}\end{array}$ \\
\hline A1 & $0.8 \mathrm{~cd}$ & $117.4 \mathrm{f}$ \\
$\mathrm{A} 2$ & $0.8 \mathrm{~cd}$ & $175.8 \mathrm{c}$ \\
P21 & $0.7 \mathrm{~d}$ & $42.9 \mathrm{j}$ \\
P22 & $0.9 \mathrm{c}$ & $72.7 \mathrm{i}$ \\
P23 & $0.7 \mathrm{~d}$ & $75.3 \mathrm{~h}$ \\
P53 & $0.9 \mathrm{c}$ & $135.5 \mathrm{~d}$ \\
B58 & $1.7 \mathrm{a}$ & $761.8 \mathrm{a}$ \\
B59 & $1.2 \mathrm{~b}$ & $115.0 \mathrm{~g}$ \\
B60 & $1.8 \mathrm{a}$ & $342.5 \mathrm{~b}$ \\
Control & $1.3 \mathrm{~b}$ & $128.7 \mathrm{e}$ \\
\hline
\end{tabular}

Note. Values in the same column followed by different letters indicate significant differences $(p<0.05)$ between the means.

in chickpea growing in drought stressed conditions. The results showed that the application of PGPR reduced the levels of stress molecules in plants. In contrast to this outcome, Reda et al. (2005) reported that PGPR isolates increased total phenols in thyme.

Based on the PGP properties and seed germination assay, 5 isolates: A1, P21, P23, P53 and B59, were selected for further evaluation for their PGP potential effect on common thyme. After 30 days, all applied isolates had a positive effect on the root and stem length of the examined thyme plant (Table 4).

The best results were achieved by using isolates $\mathrm{A} 1$ and P53. In these treatments, increase of the root and stem length was significant in both well-watered and drought-stressed conditions. In the other treatments, in well-watered conditions, the isolates enhanced the root and stem length, but the results were not significant for both measured parameters; in drought-stressed conditions, a significant increase in the root and stem length was recorded in all treatments. Results of our experiment are in accordance with many previous observations. For example, Khaosaad et al. (2006) reported the positive effect of PGPR inoculation on the shoot length and biomass of oregano plants. Abdollahi Arpanahi et al. (2019) showed that inoculation with PGPR had significant positive effect on root and shoot dry weight of endemic thyme species Thymus daenensis Celak. In the study of Yadegari et al. (2012), the application of P-solubilizing bacterium caused the highest biomass of T. vulgaris. Furthermore, many authors (Agami et al., 2016; Mohammadi et al., 2018) have already reported improved growth of medicinal plants by PGPR under drought conditions. Several authors (Cappellari et al., 2013; Çakmakç1, 2016) have indicated that PGPR inoculation increased the shoot and root biomass of different medicinal and aromatic plants. Nevertheless, Sharafzadeh et al.

Table 4. Effect of selected isolates on the stem and root length $(\mathrm{mm})$ of common thyme growing under well-watered and drought-stressed conditions

\begin{tabular}{ccccc}
\hline & \multicolumn{2}{c}{ Well-watered } & \multicolumn{2}{c}{ Drought-stressed } \\
\hline Isolate & root & stem & root & stem \\
\hline A1 & $53.3 \mathrm{a}$ & $126.8 \mathrm{a}$ & $49.2 \mathrm{a}$ & $\mathrm{a}$ \\
P21 & $41.7 \mathrm{c}$ & $111.7 \mathrm{e}$ & $31.5 \mathrm{~d}$ & $69.3 \mathrm{c}$ \\
P23 & $41.4 \mathrm{c}$ & $113.3 \mathrm{~d}$ & $32.0 \mathrm{~d}$ & $74.5 \mathrm{e}$ \\
P53 & $46.7 \mathrm{~b}$ & $116.7 \mathrm{~b}$ & $43.1 \mathrm{~b}$ & $90.7 \mathrm{~b}$ \\
B59 & $41.3 \mathrm{c}$ & $112.7 \mathrm{de}$ & $30.5 \mathrm{~d}$ & $73.5 \mathrm{e}$ \\
Control & $40.3 \mathrm{c}$ & $103.3 \mathrm{c}$ & $25.0 \mathrm{c}$ & $51.6 \mathrm{~d}$ \\
\hline
\end{tabular}

Note. Values in the same column followed by different letters indicate significant differences $(p<0.05)$ between the means. 
(2013) reported that application of Pseudomonas isolates resulted in the reduction of the shoot length of the summer savory (Satureja hortensis L.).

When the effect of applying isolates on plant growth in well-watered conditions was compared with that of applying isolates in drought-stressed conditions, it was noticed that the applied isolates had a much stronger effect on plant growth in drought-stressed conditions than in wellwatered ones. In drought-stressed conditions, the increase of stem and root length was significant in all treatments, in comparison with the control. The best results were achieved with isolates A1 and P53, both ACC-deaminaseproducing bacteria. In these treatments, the differences in root and stem length between the plants grown in wellwatered and drought-stressed conditions were smaller compared to those found in the other treatments.

Danish et al. (2019) reported that the main mechanism through which PGPR alleviates drought stress is the ACC-deaminase activity. ACC-deaminase produced by PGPR cleaves ACC into ammonia and $\alpha$-ketobutyarate, which ultimately inhibits ethylene production and improves root elongation. The ability to produce ACC-deaminase could explain why isolates A1 and B53 had the best impact on plant growth in drought-stressed conditions.

\section{Conclusion}

The results of this experiment reveal that rhizospheric bacteria of common thyme (Thymus vulgaris L.) have multiple plant growth-promoting (PGP) properties. Based on the examined characteristics of cells and colonies from the rhizosphere soil of common thyme, 9 bacterial isolates belonging to Azotobacter (denoted by the letter A), 12 to Pseudomonas (denoted by the letter P) and 10 to Bacillus (denoted by the letter B) genera were isolated. Among Azotobacter, Pseudomonas and Bacillus isolates, only one isolate (P53) had all the tested PGP properties.

The applied isolates had a positive effect on seed germination, root and shoot length, vigour index and biochemical stress markers (total phenols and lipid peroxidation intensity) of common thyme seedlings. The application of selected bacterial isolates increased the root and stem length of common thyme in both well-watered and drought-stressed conditions. However, the positive effect was much stronger in drought-stressed conditions.

Theresults of this experimentled to the conclusion that isolates Azotobacter sp. A1 and Pseudomonas sp. P53, both ACC-deaminase-producing bacteria, had the best effect on plant growth in both growing conditions, which indicates their potential to be used as a biofertiliser for promoting common thyme growth.

\section{Acknowledgements}

The authors gratefully acknowledge the support of the Provincial Secretariat for Higher Education and Scientific Research of the Autonomous Province of Vojvodina, Republic of Serbia within the framework of project No. 142-451-2353/2019-02.

Received 25012021

Accepted 15062021

\section{References}

Abdollahi Arpanahi A., Feizian M., Mehdipourian G. 2019. Plant growth promoting rhizobacteria enhance oil content and physiological status of Thymus daenensis Celak. under drought stress. Journal of Herbal Drugs, 9 (4): 223-231.

Agami R. A., Medani R. A., Abd El-Mola I. A., Taha R. S. 2016. Exogenous application with plant growth promoting rhizobacteria (PGPR) or proline induces stress tolerance in basil plants (Ocimum basilicum L.) exposed to water stress. International Journal of Environmental and Agriculture Research, 2 (5): 78-92.

Ahmed E. A., Hassan E. A., El Tobgy K. M. K., Ramadan E.M. 2014. Evaluation of rhizobacteria of some medicinal plants for plant growth promotion and biological control. Annals of Agricultural Science, 59 (2): 273-280.

https://doi.org/10.1016/j.aoas.2014.11.016

Aini N., Dwi Yamika W. S., Ulum B. 2019. Effect of nutrient concentration, PGPR and AMF on plant growth, yield and nutrient uptake of hydroponic lettuce. International Journal of Agriculture and Biology, 21 (1): 75-183.

https://doi.org/10.37855/jah.2019.v21i02.20

Çakmakçı R. 2016. Screening of multi-trait rhizobacteria for improving the growth, enzyme activities, and nutrient uptake of tea (Camellia sinensis). Communications in Soil Science and Plant Analysis, 47 (13-14): 1680-1690. https://doi.org/10.1080/00103624.2016.1206559

Cappellari L., Santoro M. V., Nievas F., Giordano W., Banchio E. 2013. Increase of secondary metabolite content in marigold by inoculation with plant growth-promoting rhizobacteria. Applied Soil Ecology, 70: 16-22. https://doi.org/10.1016/j.apsoil.2013.04.001

Danish S., Zafar-ul-Hye M., Hussain M., Shaaban M., NúñezDelgado A., Hussain S., Qayyum M. F. 2019. Rhizobacteria with ACC-deaminase activity improve nutrient uptake, chlorophyll contents and early seedling growth of wheat under PEG-induced osmotic stress. International Journal of Agriculture and Biology, 21 (6): 1212-1220.

https://doi.org/10.17957/IJAB/15.1013

Etesami H., Alikhani H. A., Hosseini H. M. 2015. Indole-3acetic acid (IAA) production trait, a useful screening to select endophytic and rhizosphere competent bacteria for rice growth promoting agents. MethodsX, 2: 72-78.

https://doi.org/10.1016/j.mex.2015.02.008

Frey-Klett P., Chavatte M., Clausse M.-L., Courrier S., Le Roux C., Raaijmakers J., Martinotti M. G., Pierrat J.-C., Garbaye J. 2005. Ectomycorrhizal symbiosis affects functional diversity of rhizosphere fluorescent pseudomonads. The New Phytologist, 165 (1): 317-328.

https://doi.org/10.1111/j.1469-8137.2004.01212.x

Ghorbanpour M., Hatami M. 2013. PGPR strains affect seedling vigor index and seed secondary metabolites accumulation of black henbane under drought stress. Trakia Journal of Sciences, 11 (2): 135-143.

Ghorbanpour M., Hatami M., Kariman K., Khavazi K. 2015. Enhanced efficiency of medicinal and aromatic plants by PGPRs. Egamberdieva D. et al. (eds). Plant-GrowthPromoting Rhizobacteria (PGPR) and Medicinal Plants. Soil Biology, vol. 42, chapter 3, p. 43-70. https://doi.org/10.1007/978-3-319-13401-7_3

Gusain P., Bhandari B. S. 2019. Rhizosphere associated PGPR functioning. Journal of Pharmacognosy and Phytochemistry, 8 (5): 1181-1191. 
Heydari S., Rezvani Moghadam P., Arab S. M. 2008. Hydrogen cyanide production ability by Pseudomonas fluorescence bacteria and their inhibition potential on weed germination. Competition for Resources in a Changing World: New Drive for Rural Development. Book of abstracts, $4 \mathrm{p}$.

Jahanian A., Chaichi M. R., Rezaei K., Rezayazdi K., Khavazi K. 2012. The effect of plant growth promoting rhizobacteria (PGPR) on germination and primary growth of artichoke (Cynara scolymus). International Journal of Agriculture and Crop Sciences, 4: 923-929.

Jambunathan N. 2010. Determination and detection of reactive oxygen species (ROS), lipid peroxidation, and electrolyte leakage in plants. Methods in Molecular Biology, 639: 292-298. https://doi.org/10.1007/978-1-60761-702-0_18

Kenneth O. C., Nwadibe E. C., Kalu A., Unah U. V. 2019. Plant growth promoting rhizobacteria (PGPR): a novel agent for sustainable food production. Review article. American Journal of Agricultural and Biological Sciences, 14 (1): $35-54$

https://doi.org/10.3844/ajabssp.2019.35.54

Khaosaad T., Vierheilig H., Nell M., Zitterl-Eglseer K., Novak J. 2006. Arbuscular mycorrhiza alter the concentration of essential oils in oregano (Origanum sp., Lamiaceae). Mycorrhiza, 16: 443-446. https://doi.org/10.1007/s00572-006-0062-9

Köberl M., Schmidt R., Ramadan E. M., Bauer R., Berg G. 2013. The microbiome of medicinal plants: diversity and importance for plant growth, quality, and health. Frontiers in Microbiology, 4: 400. https://doi.org/10.3389/fmicb.2013.00400

Kumar M., Mishra S., Dixit V., Kumar M., Agarwal L., Singh Chauhan P., Nautiyal C. S. 2016. Synergistic effect of Pseudomonas putida and Bacillus amyloliquefaciens ameliorates drought stress in chickpea (Cicer arietinum L.). Plant Signaling and Behavior, 11 (1): e1071004. https://doi.org/10.1080/15592324.2015.1071004

Lenin G., Jayanthi M. 2012. Efficiency of plant growth promoting rhizobacteria (PGPR) on enhancement of growth, yield and nutrient content of Catharanthus roseus. International Journal of Research in Pure and Applied Microbiology, 2 (4): 37-42.

Liu H., Wu X.-Q., Ren J.-H., Ye J.-R. 2011. Isolation and identification of phosphobacteria in poplar rhizosphere from different regions of China, Pedosphere, 21 (1): 90-97. https://doi.org/10.1016/S1002-0160(10)60083-5

Makkar H. P. S., Siddhuraju P., Becker K. 2007. Plant secondary metabolites. Methods in Molecular Biology, 393: 1-122. https://doi.org/10.1007/978-1-59745-425-4 1

Malik A. A., Suryapani S., Ahmad J. 2011. Chemical vs organic cultivation of medicinal and aromatic plants: the choice is clear. International Journal of Medicinal and Aromatic Plants, 1 (1): 5-13.

Malleswari D., Bagyanarayan G. 2013. In vitro screening of rhizobacteria isolated from the rhizosphere of medicinal and aromatic plants for multiple plant growth promoting activities. Journal of Microbiology and Biotechnology Research, 3 (1): 84-91.

Mohammadi H., Esmailpour M., Ghorabi S., Hatami M. 2018. Physiological and biochemical changes in Matricaria chamomilla induced by Pseudomonas fluorescens and water deficit stress. Acta Agriculturae Slovenica, 111 (1) 63-72. https://doi.org/10.14720/aas.2018.111.1.07
Nguyen P. M., Niemeyer E. D. 2008. Effect of nitrogen fertilization on the phenolic composition and antioxidant properties of basil (Ocimum basilicum L.). Journal of Agricultural and Food Chemistry, 56 (18): 8685-8691. https://doi.org/10.1021/jf801485u

Pastor N., Masciarelli O., Fischer S., Luna V., Rovera M. 2016. Potential of Pseudomonas putida $\mathrm{PCI}_{2}$ for the protection of tomato plants against fungal pathogens. Current Microbiology, 73: 346-353. https://doi.org/10.1007/s00284-016-1068-y

Pilli K., Mukherjee S., Sengupta S. 2019. Strategies for improving Agricultural productivity under climate change scenario. Agriculture and Food: e-Newsletter, $1(8)$ : 353-356.

Rathaur P., Ramteke W. P., Raja W., Ashish J. S. 2012. Isolation and characterization of nickel and cadmium tolerant plant growth promoting rhizobacteria from rhizosphere of Withania somnifera. Journal of Biological and Environmental Sciences, 6 (18): 253-261. http://hdl. handle.net/11452/17746

Reda F., Abdel-Rahim E. A., El-Baroty G. S. A., Ayad H. S. 2005. Response of essential oils, phenolic components and polyphenol oxidase activity of thyme (Thymus vulgaris L.) to some bioregulators and vitamins. Journal of Agriculture and Biological Science, 7 (5): 735-739.

Schwyn B., Neilands J. B. 1987. Universal chemical assay for the detection and determination of siderophores. Analytical Biochemistry, 160 (1): 47-56. https://doi.org/10.1016/0003-2697(87)90612-9

Shakeela S., Padder S. A., Bhat Z. A. 2017. Isolation and characterization of plant growth promoting rhizobacteria associated with medicinal plant Picrorhiza kurroa. Journal of Pharmacognosy and Phytochemistry, 6 (3): 157-168.

Sharafzadeh S., Sabahi A., Ordookhani K., Zare M. 2013. Growth and active substances of summer savory as affected by PGPR. Journal of Novel Applied Sciences, 2(2S): 997-1000.

Shaukat K., Affrasayab S., Hasnain S. 2006. Growth responses of Helianthus annus to plant growth promoting rhizobacteria used as a biofertilizers. Journal of Agricultural Research, 1 (6): 573-581. https://doi.org/10.3923/ijar.2006.573.581

Siddiqui I. A., Shaukat S. S., Sheikh I. H., Khan A. 2006. Role of cyanide production by Pseudomonas fluorescens $\mathrm{CHA} 0$ in the suppression of root-knot nematode, Meloidogyne javanica in tomato. World Journal of Microbiology and Biotechnology, 22: 641-650. https://doi.org/10.1007/s11274-005-9084-2

Soesanto L., Mugiastuti E., Rahayuniati R. F. 2011. Biochemical characteristic of Pseudomonas fluorescens P60. Journal of Biotechnology and Biodiversity, 2: 19-26.

Stamenov D., Đurić S., Hajnal-Jafari T. 2014. Effect of PGPR on the germination and growth of English ryegrass and microbiological activity in its rhizosphere. Journal of Contemporary Agriculture, 63 (1-2): 79-85.

Vejan P., Abdullah R., Khadiran T., Ismail S., Nasrulhaq Boyce A. 2016. Role of plant growth promoting rhizobacteria in agricultural sustainability - a review. Molecules, 21 (5): 573.

https://doi.org/10.3390/molecules21050573

Wahyudi A. T., Astuti R. P., Widyawati A., Meryandini A., Nawangsih A. A. 2011. Characterization of Bacillus sp. strains isolated from rhizosphere of soybean plants for their use as potential plant growth for promoting Rhizobacteria. 
Journal of Microbiology and Antimicrobials, 3 (2): 34-40. http://repository.ipb.ac.id/handle/123456789/54530

Yadegari M., Farahani G. H. N. Mosadeghzad Z. 2012. Biofertilizers effects on quantitative and qualitative yield of thyme (Thymus vulgaris). African Journal of Agricultural Research, 7 (34): 4716-4723.

https://doi.org/10.5897/AJAR11.2347

Yasmin H., Nosheen A., Naz R., Keyani R., Anjum S. 2019. Regulatory role of rhizobacteria to induce drought and salt stress tolerance in plants. Maheshwari D., Dheeman S. (eds). Field Crops: Sustainable Management by PGPR. Sustainable Development and Biodiversity, vol. 23. Springer. https://doi.org/10.1007/978-3-030-30926-8_11

Zhang M., Yang L., Hao R., Bai X., Wang Y., Yu X. 2020. Drought-tolerant plant growth-promoting rhizobacteria isolated from jujube (Ziziphus jujuba) and their potential to enhance drought tolerance. Plant and Soil, 452: 423-440. https://doi.org/10.1007/s11104-020-04582-5

\title{
Vietinès kilmės pašaknio bakterijos skatina paprastojo čiobrelio (Thymus vulgaris L.) augimą drẻgname ir sausame dirvožemyje
}

\author{
D. Stamenov ${ }^{1}$, S. Djuric ${ }^{1}$, T. Hajnal-Jafari ${ }^{1}$, S. Andjelković ${ }^{2}$ \\ ${ }^{1}$ Novi Sado universiteto Žemès ūkio fakultetas, Serbija \\ ${ }^{2}$ Pašarinių augalų institutas, Serbija
}

\section{Santrauka}

Siekiant mažinti chemizaciją, labai svarbu auginant vaistinius augalus panaudoti jų augimą skatinančias pašaknio bakterijas. Tyrimo tikslas - apibūdinti bakterijas Bacillus, Pseudomonas ir Azotobacter, išskirtas iš čiobrelių pašaknio, ir nustatyti jų poveiki sẻklų dygimui bei daigų augimui. Kontroliuojamomis sąlygomis tirta išskirtų pašaknio bakterijų įtaka čiobrelių sẻklų dygimui bei daigų augimui ir ịtampos biocheminiams žymekliams (lipidų peroksidacijos intensyvumui ir suminiam fenolių kiekiui). Čiobrelius auginant vazonuose, pašaknio bakterijų įtaka augalų augimui įvertinta matuojant augalo šaknies ir stiebo ilgị pakankamai drékinant, kai dirvožemis laistytas iki 80 \% vandens sulaikymo gebos (VSG) ir sukuriant vandens trūkumą, kai laistyta iki 40 \% VSG.

Vietinès kilmės pašaknio bakterijos skatino čiobrelių augimą. Tarp išskirtų 10 Bacillus (B izoliatai), 12 Pseudomonas (P izoliatai) ir 9 Azotobacter (A izoliatai) pašaknio bakterijų pagal visus tirtus rodiklius tik Pseudomonas P53 izoliatas skatino augimą. Čiobreliai geriausiai dygo ( $96 \%$ daigumas) apdorojus P53 izoliatu, o didžiausias gyvybingumo indekso rodiklis (3807 \%) pasiektas panaudojus A1 izoliatą. Visi izoliatai, išskyrus B58 ir B60, mažino ịtampą sumažindami abiejų arba bent vieno atspindinčio ịtampą junginio kiekị.

Išvada: A1 ir P53 izoliatai, gaminantys ACC-deaminazę, labiausiai skatina augimą ir pakankamo drègnio, ir sausame dirvožemyje, todèl gali būti naudojami kaip čiobrelių biologinè trąša.

Reikšminiai žodžiai: ACC-deaminazè, biologinès trąšos, sausra, vaistiniai augalai. 